\title{
Evaluation of the Pharmacokinetics and Hepatoprotective Effects of Phillygenin in Mouse
}

\author{
Wei Song, ${ }^{1,2}$ Junjun $\mathrm{Wu}^{3}$ Longjiang Yu, ${ }^{2}$ and Zhihong Peng $\mathbb{D}^{1}$ \\ ${ }^{1}$ Hubei Province Key Laboratory of Biotechnology of Chinese Traditional Medicine, Department of Life Science, National \& Local \\ Joint Engineering Research Center of High-Throughput Drug Screening Technology, Hubei University, Wuhan 430062, China \\ ${ }^{2}$ Institute of Resource Biology and Biotechnology, Department of biotechnology, College of Life Science and Technology, \\ Huazhong University of Science and Technology, Wuhan 430074, China \\ ${ }^{3}$ Lab of Structure Biology and Medicinal Chemistry, Hubei University of Arts and Science, Xiangyang 441053, China \\ Correspondence should be addressed to Zhihong Peng; zpeng1@nd.edu
}

Received 6 January 2018; Revised 17 July 2018; Accepted 1 August 2018; Published 23 August 2018

Academic Editor: Kusum Kharbanda

Copyright (C) 2018 Wei Song et al. This is an open access article distributed under the Creative Commons Attribution License, which permits unrestricted use, distribution, and reproduction in any medium, provided the original work is properly cited.

\begin{abstract}
Phillygenin is a bioactive intergradient in Osmanthus fragrans, a well-known food additive and Chinese traditional medicine. This study was to investigate the hepatoprotective effects and pharmacokinetics of phillygenin. The hepatoprotective effect of phillygenin was assessed in carbon tetrachloride- $\left(\mathrm{CCl}_{4}-\right)$ intoxicated mice by monitoring levels of serum and tissue biomarkers. The pharmacokinetics of phillygenin was evaluated in the mouse after oral ( $p o, 24 \mathrm{mg} / \mathrm{kg}$ ) or intravenous ( $\mathrm{iv}, 12 \mathrm{mg} / \mathrm{kg}$ ) administration. Results showed that phillygenin has a great hepatoprotective effect on CCl4-induced liver injury in mice owing to its antioxidant activity and inhibition on cytochrome P450 2E1(CYP2E1). After oral administration, phillygenin was efficiently absorbed with the oral bioavailability of $56.4 \%$. Two metabolites, hydroxylated and dimethylated phillygenin, were identified in mouse urine. These results suggested that phillygenin could be explored as new and potential natural antioxidants and hepatoprotective agents.
\end{abstract}

\section{Introduction}

Osmanthus fragrans is a plant belonging to the Oleaceae family [1], which has been cultivated and distributed in East Asia, spanning a large geographic region through China to Japan [2]. Osmanthus fragrans flower is not only valued as an additive for tea and various foods but also used as cosmetics for hair and skin and aromatic therapy [1]. In addition, Osmanthus fragrans flower has a wide range of pharmacological properties including antioxidation [3], neuroprotection [4], and antimicrobial effects [5]. Our lab has found that Osmanthus fragrans flower extract (OFE) showed a great hepatoprotective effect on $\mathrm{CCl}_{4}$-induced hepatic injury mice [2].

Phillygenin, extracted from Osmanthus fragrans flower for the first time by our group [6], has many medicinal properties. It can reduce blood lipid levels [7] and low density lipoprotein [8]. It is also useful in therapeutic and preventive applications in treating ONOO-related diseases [9]. Although phillygenin has many pharmacological activities, there is limited hepatoprotective information on phillygenin.
What is more, to reflect the absorption and the first pass effect with which a drug is absorbed after oral administration, its oral bioavailability should be assessed, but the information of phillygenin pharmacokinetics is still limited [10,11]. Present study primarily aims to evaluate the hepatoprotective of the OFE and its main bioactive component phillygenin on CCl4-induced hepatic injury mice. The pharmacokinetics and metabolism of phillygenin in mice are also studied.

\section{Materials and Methods}

2.1. Chemicals and Reagents. Phillygenin (purity > 98.6\%) was extracted and purified from Osmanthus fragrans by our laboratory [6]. Ethylenediamine tetracetic acid (EDTA), pyrogallic acid, ammonium thiocyanate, potassium persulfate, ferrous chloride, ascorbic acid (purity > 98.0\%), 2,4,6-tripyridyl-s-triazine and ferric chloride, diphenyl-2picrylhydrazyl (DPPH), diethyldithiocarbamate, chlorzoxazone, 6-hydroxy chlorzoxazone, and $\beta$-Nicotinamide adenine dinucleotide $2^{\prime}$-phosphate reduced tetrasodium salt 
hydrate (NADPH) were purchased from Sigma-Aldrich (St. Louis, USA). All other chemicals and solvents were of chromatography grade. Human recombinant human CYP2E1 was purchased from BD Biosciences (San Diego, USA).

Liquid chromatography grade solvents were purchased from Sigma-Aldrich (St. Louis, USA). Purified water (MilliQ Advantage, Millipore, Worcester, USA) was used for all preparations. The stock solution of phillygenin was prepared in acetonitrile and stored at $-20^{\circ} \mathrm{C}$. Bifendate (purity > 98.0\%) (batch number: 110405, Zhejiang Medicine Co. Ltd., Xinchang Pharmaceutical Factory, Xinchang, China) was used as positive control in the hepatoprotective study.

2.2. Preparation of the OFE. The flower of Osmanthus fragrans was collected from Wuhan, Hubei Province, China, in October 2010. The fresh flowers were dried naturally and extracted by petroleum ether $(w: w, 1: 3)$ at room temperature for 2 hours using a shaker for three times. The extracts were filtrated and then dried by vacuum rotary evaporator to yield OFE. The OFE was dissolved in olive oil for the hepatoprotective study on animals.

\subsection{Antioxidants Assay}

2.3.1. DPPH Radical-Scavenging Activity Assay. DPPH radical-scavenging activity was determined using a modified method $[12,13]$. The reaction system contained $1.0 \mathrm{ml}$ of DPPH solution $(0.3 \mathrm{mM}$ in methanol $)$ and $2.5 \mathrm{ml}$ sample solution (dissolved in methanol). The absorbance was detected at $515 \mathrm{~nm}$ after the mixture was shaken vigorously and incubated at room temperature for $30 \mathrm{~min}$. The scavenging effect was determined as follows:

$$
\mathrm{DPPH} \% \text { inhibition }=\left[\frac{(\mathrm{A} 1-\mathrm{A} 2)}{\mathrm{A} 1}\right] \times 100,
$$

where $\mathrm{Al}$ is the absorbance in the absence of the sample and $\mathrm{A} 2$ represents the absorbance in the presence of the sample.

2.3.2. ABTS Radical-Scavenging Activity Assay. The procedures for ABTS assay followed the method $[13,14]$ with some modifications. $7.0 \mathrm{mM}$ ABTS solution and $5.0 \mathrm{mM}$ potassium persulfate solution were mixed in equal quantities and stored at room temperature in the dark for $14 \mathrm{~h}$ to get $\mathrm{ABTS}^{+}$solution. The solution was then diluted by mixing $1 \mathrm{~mL} \mathrm{ABTS}{ }^{+}$ solution with $60 \mathrm{~mL}$ methanol to obtain an absorbance of $0.70 \pm 0.02$ units at $734 \mathrm{~nm}$ using the spectrophotometer. Phillygenin $(200 \mu \mathrm{L})$ was mixed with $3.0 \mathrm{~mL}$ of the $\mathrm{ABTS}^{+}$ solution for $15 \mathrm{~min}$ in a dark condition. The absorbance was detected at $734 \mathrm{~nm}$ on a biotech spectrophotometer (VT, US). The result was expressed as IC50 value.

2.4. Assessment of the Effect of Phillygenin on CYP2E1. To assess the potential of phillygenin to inhibit CYP2E1, the formation of chlorzoxazone 6-hydroxylation was used to assay the activity of CYP2E1 in the presence and absence of phillygenin. Seven phillygenin concentrations (0.01-10 $\mu \mathrm{M})$ were used. In brief, to determine the IC50 values, a mixture $(200 \mu \mathrm{L})$ containing phosphate buffer $(50 \mathrm{mM}$, $\mathrm{pH}$ 7.4), chlorzoxazone $(10 \mu \mathrm{M})$, and CYP2E1 (40 pmol of protein $/ \mathrm{mL}$ ) was prepared for each. After preincubation at $37^{\circ} \mathrm{C}$ for $5 \mathrm{~min}, 10 \mu \mathrm{L}$ of NADPH $(20 \mathrm{mM})$ was added to initiate the reaction. Positive control experiments were run in parallel by incubating each probe substrate at $37^{\circ} \mathrm{C}$ in duplicate with CYP2E1 in the absence (control) and the presence of diethyldithiocarbamate (a specific inhibitor of CYP2E1) [15]. The organic solvent was removed by drying of the solution in a speed vacuum concentrator (Genevac Ltd., Suffolk, UK). After incubation, $400 \mu \mathrm{L}$ acetonitrile containing internal standard was added to stop the reaction. The experimental samples were centrifuged at $10,000 \times \mathrm{g}$ for $20 \mathrm{~min}$, and then the supernatants were transferred to new vials and concentrated by drying of the solution in a speed vacuum concentrator. The residues were redissolved in $100 \mu \mathrm{L}$ acetonitrile/water (50/50, v/v) and analyzed by ultraperformance liquid chromatography (UPLC) with multiplereaction monitoring (MRM) detection.

Waters Acquity UPLC with a reversed column (Aquity UPLC C18, $1.7 \mu \mathrm{m}, 2.1 \mathrm{~mm}$ i.d. $\times 100 \mathrm{~mm}$ ) was used to analyze the samples. The flow rate was $0.5 \mathrm{~mL} / \mathrm{min}$ with $90 \% \mathrm{~A} / 10 \% \mathrm{~B}$ for $2 \mathrm{~min}$, followed by a 7 -min linear gradient to $10 \% \mathrm{~A} / 90 \%$ $\mathrm{B}$, then hold for $4 \mathrm{~min}(\mathrm{~A}=$ water, $\mathrm{B}=$ acetonitrile $)$. Mass spectrometric experiments were carried out with a Waters TQD tandem quadrupole detector (Milford, MA, USA) using electrospray negative ionization mode. The capillary voltage, cone voltage, extractor voltage, and RF lens voltage were set at $2.8 \mathrm{kV}, 35 \mathrm{~V}, 3.0 \mathrm{~V}$, and $0.3 \mathrm{~V}$, respectively. Nitrogen was used as desolvation gas $(650 \mathrm{~L} / \mathrm{h})$ and cone gas $(50 \mathrm{~L} / \mathrm{h})$. The source temperature was $150^{\circ} \mathrm{C}$ and desolvation temperature was $350^{\circ} \mathrm{C}$. The MRM transition for chlorzoxazone 6hydroxylation is $184 \longrightarrow 64$.

IC50 values were determined by nonlinear regression with GraphPad Prism 5 software (GraphPadSoftware Inc., San Diego, CA). The Ki values were determined by the following equation for competitive inhibition.

$$
v=\frac{V \max [S]}{[S]+K m(1+[I] / K i)}
$$

\subsection{Pharmacodynamics Assays}

2.5.1. Animals. Mice (Male Kunming, 6-8 weeks old, 17$20 \mathrm{~g}$ body weight) were obtained from Hubei Experimental Animal Research Center, China. All animal experimental protocols involving animals were reviewed and approved by the institutional animal experimentation committee of Huazhong University of Science and Technology (No. 00019655, 01/11/2011).

\subsubsection{Hepatoprotective Effect of Osmanthus Fragrans Flower} Extract and Phillygenin. Mice ( $\mathrm{n}=9$ for each group) were separated into nine groups: normal control, $\mathrm{CCl}_{4}$ group, positive control, OFE $(150,300,600 \mathrm{mg} / \mathrm{kg})$, phillygenin $(6$, $12,24 \mathrm{mg} / \mathrm{kg}$ ). The normal control group received sterile distilled water. The positive control group mice were given bifendate by oral administration at the dose of $150 \mathrm{mg} /$ $\mathrm{kg}$ once daily for seven consecutive days and induced by 
a single injection of $\mathrm{CCl}_{4}$ (ip, $10 \mathrm{~mL} / \mathrm{kg}$ of $0.1 \%$ in olive oil) once a day from day 5 for three consecutive days. The phillygenin/OFE group mice were pretreated once a day with phillygenin by oral administration for seven consecutive days and also induced by $\mathrm{CCl}_{4}$ at the same time as the positive control group. The $\mathrm{CCl}_{4}$ group received sterile distilled water with normal mice chow and was induced by $\mathrm{CCl}_{4}$ from day 5 for three consecutive days. There are two mice dead occasionally for the $\mathrm{CCl}_{4}$ group, one mouse dead for $150 \mathrm{mg}$ / $\mathrm{kg}$ OFE group and two mice for $6 \mathrm{mg} / \mathrm{kg}$ phillygenin group. All animals were sacrificed under mild ether anesthesia $16 \mathrm{~h}$ after last $\mathrm{CCl}_{4}$ injection, and blood samples were collected immediately.

Collected blood samples were placed at room temperature for $1 \mathrm{~h}$ and then centrifuged at $1000 \times \mathrm{g}$ for $10 \mathrm{~min}$ to obtain serum. Aspartate aminotransferase (AST) and alanine aminotransferase (ALT) levels were determined with commercial kits (Nanjing Jiancheng Biological Technology, Inc., China).

Liver samples were homogenized in Tris- $\mathrm{HCl}$ buffer ( $5 \mathrm{mM}$ containing $2 \mathrm{mM}$ EDTA, $\mathrm{pH} 7.4$ ) to give $10 \%(\mathrm{w} / \mathrm{v})$ liver homogenates. The homogenates were then centrifuged at $1000 \times \mathrm{g}$ for $10 \mathrm{~min}$ at $4^{\circ} \mathrm{C}$, and the supernatants were used immediately for the determination of antioxidant status. Activities of antioxidant defense enzymes, superoxide dismutase (SOD), malondialdehyde (MDA), and protein content of the homogenates were determined with commercial kits (Nanjing Jiancheng Biological Technology, Inc., China). Liver tissues for the histopathological analysis were fixed in $10 \%$ buffered formalin saline, processed by routine histology procedures, and embedded in paraffin. Tissue sections $(4-5 \mu \mathrm{m})$ were stained with hematoxylin and eosin, observed under the microscope (NIKON TS100, Japan), and recorded.

\subsection{Pharmacokinetics Assays}

2.6.1. Samples Preparation. A $100-\mu \mathrm{L}$ aliquot of plasma was mixed with $2.5 \mu \mathrm{L}$ of internal standard (IS) in acetonitrile to a final concentration of $5 \mu \mathrm{g} / \mathrm{mL}$. The sample was centrifuged at $20000 \times \mathrm{g}$ for $15 \mathrm{~min}$. The supernatants from plasma samples were collected for UPLC-MRM analysis.

2.6.2. UPLC-MS/MS Conditions. Phillygenin analysis was carried out on a Waters Acquity UPLC System (Waters Corporation, Milford, MA, USA) equipped with a binary solvent manager, an autosampler, a column heater, and a PDA e $\lambda$ detector, scanning from 190 to $400 \mathrm{~nm}$. Separation was carried out using an Acquity BEH Shield RP C18 column $(1.7 \mu \mathrm{m}, 2.1 \mathrm{~mm}$ i.d. $\times 100 \mathrm{~mm}$, Waters $)$ eluted at $0.4 \mathrm{~mL} / \mathrm{min}$ with $0-2 \mathrm{~min}$ at $90 \% \mathrm{~A} / 10 \% \mathrm{~B}$, then $2-12$ min linear gradient from $90 \% \mathrm{~A} / 10 \% \mathrm{~B}$ to $10 \% \mathrm{~A} / 90 \% \mathrm{~B}$, and $12 \mathrm{~min}$ to $15 \mathrm{~min}$ from $10 \% \mathrm{~A} / 90 \% \mathrm{~B}$ to $10 \% \mathrm{~A} / 90 \% \mathrm{~B}$ ( $\mathrm{A}=$ water; $\mathrm{B}=$ acetonitrile).

Mass spectrometric experiments were performed on a Waters TQD tandem quadrupole detector (Milford, MA, USA) with MassLynx MS software. Phillygenin and the metabolites were analyzed in the negative ESI mode and data-dependence MS/MS scanning from m/z 100 to 1000. Conditions were as follows: capillary voltage $3.2 \mathrm{kV}$, cone voltage $25 \mathrm{~V}$, extractor voltage $3 \mathrm{~V}$, RF lens voltage $0.1 \mathrm{~V}$, desolvation nitrogen gas flow rate $650 \mathrm{~L} / \mathrm{hr}$, cone nitrogen gas flow rate $50 \mathrm{~L} / \mathrm{h}$, source temperature $147^{\circ} \mathrm{C}$, and desolvation temperature $350^{\circ} \mathrm{C}$.

\subsubsection{Method Validation}

(1) Calibration, Precision, Accuracy, and Matrix Effect. The calibration curve was prepared with $0.01-10 \mu \mathrm{g} / \mathrm{mL}$ calibration standards in mouse plasma to determine the linear range. A calibration curve was also prepared in aqueous solution and compared to the plasma calibration curve to assess potential matrix effects. Quality control (QC) samples were prepared daily for three days at three levels (low, medium, and high) in mouse plasma. The preparation of QC samples was the same as described in samples preparation. Blank plasma was spiked with standard phillygenin at final concentrations corresponding to low QC of $0.01 \mu \mathrm{g} / \mathrm{mL}$, medium QC of $1 \mu \mathrm{g} / \mathrm{mL}$, and high QC of $10 \mu \mathrm{g} / \mathrm{mL}$ in plasma.

(2) Stability and Recovery. To evaluate the stability of phillygenin in mouse plasma, low, medium, and high QCs were stored at $-80^{\circ} \mathrm{C}$ for one month for long-term stability. Shortterm room temperature (RT) stability of phillygenin in mouse plasma was assessed by analyzing QC samples stored at room temperature for $6 \mathrm{~h}$. For freeze-thaw stability of phillygenin, each set of low, medium, and high QCs was prepared in triplicate and determined after three freeze-thaw cycles $\left(-80^{\circ} \mathrm{C}\right.$ to $\left.\mathrm{RT}\right)$. The extraction efficiency of phillygenin was determined by dividing the analyte plasma concentration with the calculated aqueous QC concentration.

2.6.4. Pharmacokinetics of Phillygenin in Mice. Mice $(n=6$ per time point) were given a single oral dose of phillygenin at $24 \mathrm{mg} / \mathrm{kg}$. Terminal blood samples were collected in heparin through the posterior vena cava at $0.5,1,2,3,4,6,9,24$, and $30 \mathrm{~h}$. After iv injection of phillygenin at $12 \mathrm{mg} / \mathrm{kg}$, blood samples were collected at 2, 5, 10, 20, and $40 \mathrm{~min}$ and 1,2, 3, $4,6,18$, and $24 \mathrm{~h}$ after administration. Blood samples were stored on ice and centrifuged at $1200 \times \mathrm{g}, 4^{\circ} \mathrm{C}$ for $10 \mathrm{~min}$ to collect plasma and then stored at $-80^{\circ} \mathrm{C}$ until analysis.

2.6.5. Pharmacokinetic Parameters and Statistical Analysis. The area under the mean concentration-time curve up to the last quantifiable sampling time $\left(A U C_{0 \text {-last }}\right)$, volume distribution $(\mathrm{Vd})$, clearance $(\mathrm{Cl})$, initial concentration $\left(\mathrm{C}_{0}\right)$, elimination half-life (E Half-life), absorption half-life (A Half-life), and distribution half-life (D Half-life) was calculated by the trapezoidal rule. $A U C_{0-\infty}$ was calculated as $A U C_{0 \text {-last }+}\left(C_{\text {last }} / k\right)$, where $C_{\text {last }}$ is the concentration at the last quantifiable sampling time and $k$ is the elimination rate constant. Half-lives $\left(t_{(1 / 2) \alpha}\right.$ and $\left.t_{(1 / 2) \beta}\right)$ were determined from the linear segments of the initial or terminal linear portion of the concentration-time data by linear regression, where the slope of the line is the rate constant $k$ and $t_{(1 / 2) \alpha}=\ln 2 / k$. The oral bioavailability was calculated by the following equation:

$$
\text { Oral bioavailability }(\%)=\frac{\left(\mathrm{AUC}_{\mathrm{po}} \times \text { dose }_{\mathrm{iv}}\right)}{\left(\mathrm{AUC}_{\mathrm{iv}} \times \text { dose }_{\mathrm{po}}\right)} \times 100 \%
$$




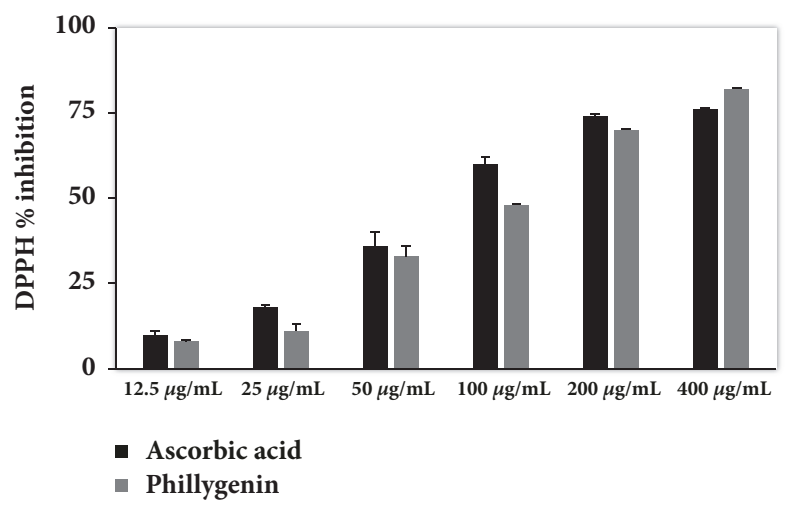

(a)

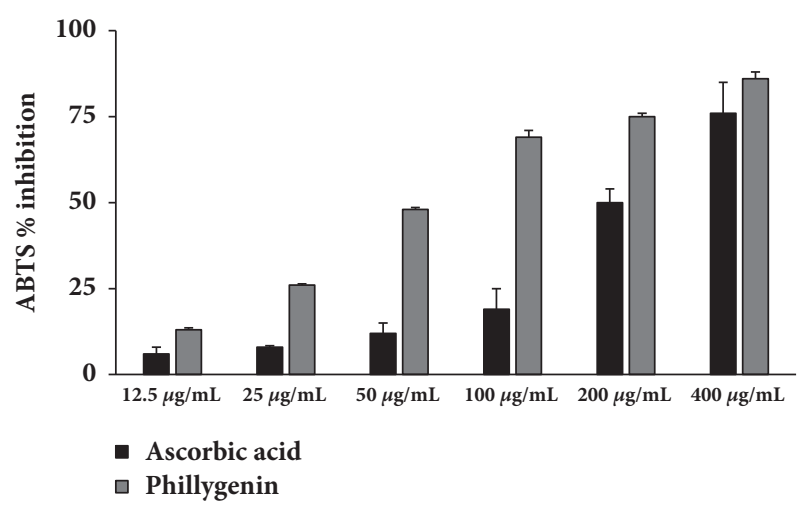

(b)

FIGURE 1: Evaluation of antioxidant activities of phillygenin using (a) DPPH and (b) ABTS methods. $(\mathrm{n}=3)$.

2.6.6. Metabolism of Phillygenin in Mouse Urine. Mice were housed in metabolic cages for the collection of urine. Mice fasted for $24 \mathrm{~h}$ but with access to water and then were given a single dose of phillygenin $(24 \mathrm{mg} / \mathrm{kg}$ weight) by oral gavage. Mice urine were collected after administration of phillygenin for $24 \mathrm{~h}$ and centrifuged at $1,000 \times \mathrm{g}$ for $10 \mathrm{~min}$; the supernatants were collected and stored at $-80^{\circ} \mathrm{C}$ until analysis.

\section{Results}

3.1. Antioxidant Activity of Phillygenin In Vitro. Antioxidant activity of phillygenin was evaluated in vitro. Figure 1 shows DPPH and ABTS radical-scavenging activities of phillygenin and ascorbic acid at different concentrations. The results demonstrated that both of phillygenin and ascorbic acid could eliminate DPPH and ABTS radicals in a dose-dependent manner. The quality of antioxidants was determined by IC50 values (antioxidant concentration that reduces the DPPH/ ABTS radical by 50\%). The results show that the phillygenin had potent DPPH (IC50 $102 \pm$ $4.17 \mu \mathrm{g} / \mathrm{mL}$ ) and ABTS (IC50 $49.0 \pm 4.25 \mu \mathrm{g} / \mathrm{mL}$ ) free-radical scavenging activity.

3.2. Inhibition of CYP2E1 by Phillygenin. Inhibition studies allowed the calculation of $\mathrm{IC}_{50} \mathrm{~s}$ and $K_{\mathrm{i}}$ values and the determination of the type of inhibition for CYP2E1. The results indicated that phillygenin showed potent inhibition of CYP2E1 with $\mathrm{IC}_{50}$ of $4.50 \mu \mathrm{M}$ (Figure 2(a)). Relatively higher $\mathrm{IC}_{50}(8.91 \mu \mathrm{M})$ of diethyldithiocarbamate was seen for CYP2E1 when chlorzoxazone was used as a probe. Phillygenin inhibited CYP2E1 activity with $K_{\mathrm{i}}$ of $2.40 \mu \mathrm{M}$, and the Lineweaver-Burk plot (Figure 2(b)) was consistent with a competitive inhibition profile.

3.3. Hepatoprotective Effects of OFE/ Phillygenin on CCl4Induced Mice Liver Injury. The effects of phillygenin/OFE on liver antioxidant status are presented in Table 1. The serum levels of hepatic enzymes AST and ALT, used as biochemical markers for evaluation of early hepatic injury, were significantly elevated $(\mathrm{p}<0.01)$ in the CCl4-treated mice. Pretreatment with phillygenin or OFE significantly prevented the elevation of these marker enzymes $(p<0.05)$, compared to the negative control model group animals. A significant increase in MDA level $(\mathrm{p}<0.01)$, an indicator of lipid peroxidation, was found in the livers of CCl4intoxicated mice relative to normal mice. Pretreatment with different doses of phillygenin /OFE reversed this biochemical parameter significantly towards normal level $(p<0.05)$. The activities of antioxidant enzymes SOD in liver homogenates were significantly decreased $(p<0.01)$ in liver injury model groups when compared to normal controls. The results show that phillygenin/OFE exerts a beneficial effect on antioxidant enzymes $(p<0.01)$. The activities of AST, SOD, and MDA after treatment with the lowest dosage of phillygenin/OFE showed almost the same levels after treatment with bifendate, the potent hepatoprotective drug used as positive control [16$18]$.

The histological examination showed no pathological abnormalities in the liver of normal control animals (Figure 3(a)). However, histopathological analysis of the liver sections of $\mathrm{CCl}_{4}$-treated animals showed a moderate degree of centrilobular necrosis, hepatocyte ballooning, and infiltration of inflammatory cells into the portal tract and sinusoid in the necrotic lesion (Figure 3(b)). Pretreatment with phillygenin/OFE reversed the hepatic lesions produced by $\mathrm{CCl}_{4}$ as it is evident from the absence of cellular necrosis and inflammatory infiltrates in the liver section of treated mice (Figures 3(d)-3(i)), which were almost comparable to those of the normal control and bifendate (Figure 3(c)) treated groups.

3.4. Pharmacokinetics of Phillygenin. The method developed (Supplementary Material available here) was successfully applied to determine the plasma concentrations of phillygenin in mice following oral ( $p o, 24 \mathrm{mg} / \mathrm{kg}$ ) or intravenous (iv, $12 \mathrm{mg} / \mathrm{kg}$ ) administration. The plasma concentrationtime profiles of phillygenin are presented in Figure 4, and their corresponding pharmacokinetic parameters are summarized in Table 2; the $A U C_{0 \text {-last }}$ is $72.5 \mathrm{~min} \bullet \mu \mathrm{g} / \mathrm{mL}$. The $A U C_{0 \text {-last }}$ of phillygenin after iv administration of $12 \mathrm{mg} / \mathrm{kg}$ is $63.2 \mathrm{~min} \bullet \mu \mathrm{g} / \mathrm{mL}$, pharmacokinetic parameters are presented 
TABLE 1: Effect of phillygenin/OFE on AST, ALT, SOD, and MDA activities in blood serum of normal and experimental mice $(\mathrm{n}=6)$.

\begin{tabular}{|c|c|c|c|c|}
\hline & $\begin{array}{c}\text { ALT } \\
(\mathrm{nmol} /(\mathrm{s} \mathrm{L}))\end{array}$ & $\begin{array}{c}\mathrm{AST} \\
(\mathrm{nmol} /(\mathrm{s} \mathrm{L}))\end{array}$ & $\begin{array}{c}\text { SOD } \\
\text { (U/mg protein) }\end{array}$ & $\begin{array}{c}\text { MDA } \\
\text { (nmol/mg } \\
\text { protein) }\end{array}$ \\
\hline normal control & $42.0 \pm 7.26$ & $183 \pm 16.8$ & $52.8 \pm 4.90$ & $1.75 \pm 0.482$ \\
\hline $\mathrm{CCl}_{4}$ control & $271 \pm 92.0^{* *}$ & $278 \pm 35.6^{* *}$ & $39.2 \pm 5.17^{* *}$ & $2.54 \pm 0.251^{* *}$ \\
\hline positive control & $70.0 \pm 18.3^{\# \#}$ & $186 \pm 10.4^{\# \#}$ & $47.2 \pm 2.95^{\# \#}$ & $1.81 \pm 0.270^{\# \#}$ \\
\hline $150 \mathrm{mg} / \mathrm{kg}$ OFE & $111 \pm 43.1^{\# \#}$ & $175 \pm 15.5^{\# \#}$ & $46.5 \pm 4.25^{\#}$ & $1.82 \pm 0.541^{\#}$ \\
\hline $300 \mathrm{mg} / \mathrm{kg}$ OFE & $109 \pm 23.2^{\# \#}$ & $171 \pm 30.4^{\# \#}$ & $45.9 \pm 2.65^{\#}$ & $1.79 \pm 0.250^{\# \#}$ \\
\hline $600 \mathrm{mg} / \mathrm{kg}$ OFE & $99.0 \pm 25.7^{\# \#}$ & $178 \pm 24.9^{\# \#}$ & $46.5 \pm 3.63^{\#}$ & $1.76 \pm 0.430^{\# \#}$ \\
\hline $6 \mathrm{mg} / \mathrm{kg}$ phillygenin & $111 \pm 30.5^{\# \#}$ & $190 \pm 29.2^{\# \#}$ & $46.4 \pm 4.27^{\#}$ & $1.85 \pm 0.820$ \\
\hline $12 \mathrm{mg} / \mathrm{kg}$ phillygenin & $112 \pm 23.1^{\# \#}$ & $196 \pm 28.4^{\# \#}$ & $46.9 \pm 2.74^{\# \#}$ & $1.91 \pm 0.224^{\# \#}$ \\
\hline $24 \mathrm{mg} / \mathrm{kg}$ phillygenin & $110 \pm 16.4^{\# \#}$ & $192 \pm 20.8^{\# \#}$ & $49.5 \pm 6.89^{\#}$ & $1.92 \pm 0.413^{\#}$ \\
\hline
\end{tabular}

$* p<0.05, * * p<0.01$ versus normal control group.

$\# p<0.05,{ }^{\#} p<0.01$, versus $\mathrm{CCl}_{4}$ control group.

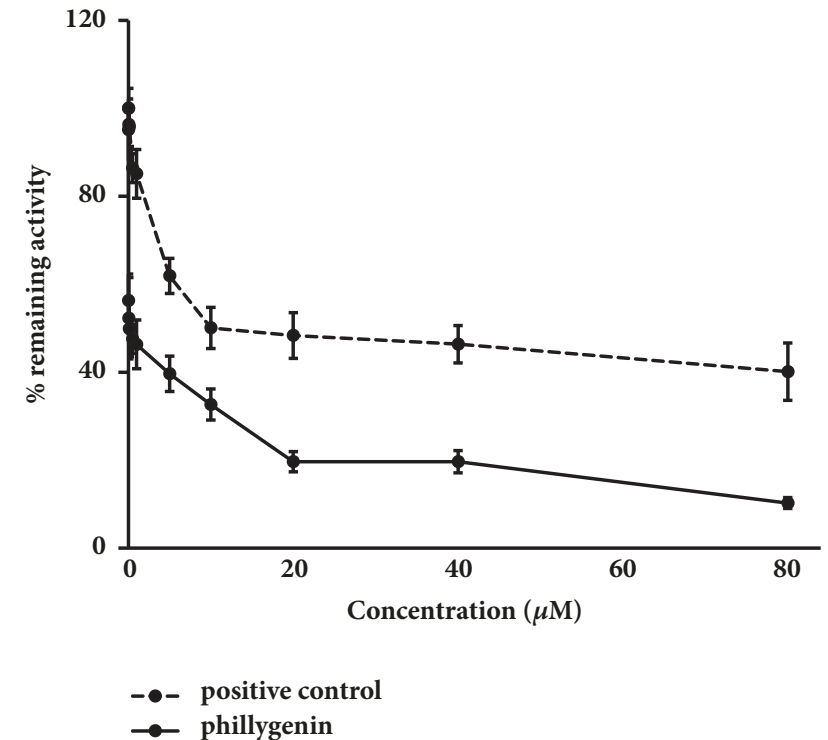

(a)

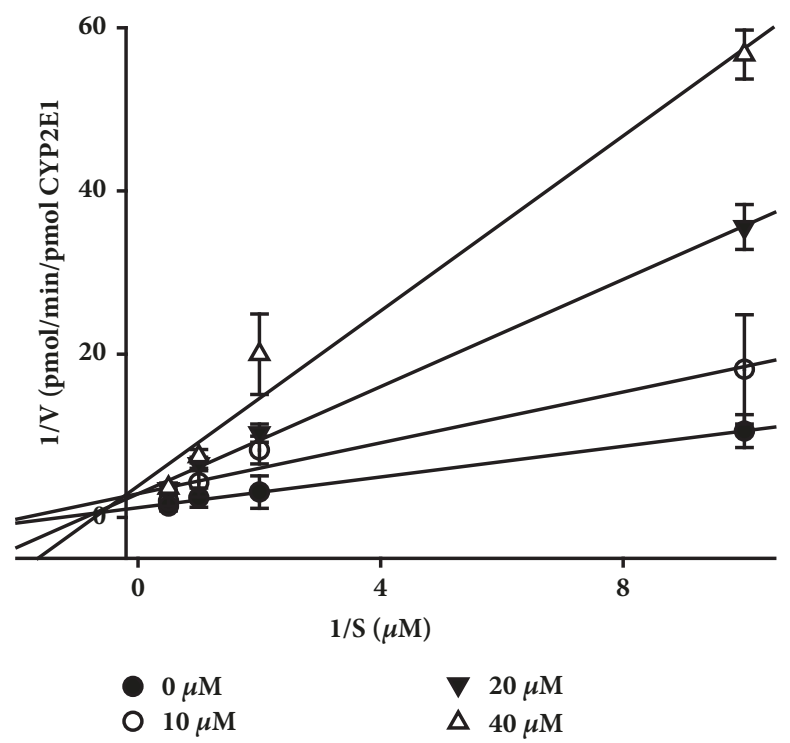

(b)

FIGURE 2: Inhibition of recombinant human CYP2E1 enzymes by phillygenin. (a) Chlorzoxazone at a concentration near its Km was incubated with CYP2E1 enzymes and cofactors in the presence of diethyldithiocarbamate (positive control) (0 to $80 \mu \mathrm{M})$ or phillygenin $(0$ to 80 $\mu \mathrm{M})$. Each point represents the average of duplicate incubations. (b). Lineweaver-Burk plots showing the inhibition of CYP2E1-catalyzed chlorzoxazone 6-hydroxylation by phillygenin $(0,10,20$, and $40 \mu \mathrm{M})$ in human recombinant human CYP2E1 enzymes. Each data point represents the average of duplicate experiments.

in Table 2, and the plasma concentration versus time curves are shown in Figure 4. After oral administration, phillygenin was quickly absorbed, reaching maximum levels at $30 \mathrm{~min}$. The phillygenin was slowly distributed to tissues, with a halflife of $150 \mathrm{~min}$. The elimination a half-live was $240 \mathrm{~min}$. Oral bioavailability of phillygenin in mouse is $56.4 \%$.

3.5. Metabolism of Phillygenin in Mice. The LC-MS and LCMS/MS analyses of phillygenin were performed in electrospray negative ion mode. The full-scan mass spectrum of phillygenin gave protonated molecular ion $[\mathrm{M}-\mathrm{H}]^{-}$at $\mathrm{m} / \mathrm{z}$ 371. The $\mathrm{MS}^{2}$ spectrum of the molecular ion contains five main product ions at $\mathrm{m} / \mathrm{z} 356,163,151,136$, and 121 .
The proposed fragmentation of phillygenin was shown in Figure 5. The product ions and the corresponding neutral fragment loss were the characteristic structural information of phillygenin and were the sound basis to identify metabolites of phillygenin. Possible metabolite structures were considered based on the structure of phillygenin and known common metabolic pathways. Phillygenin and its two metabolites with their protonated molecular ions [M $\mathrm{H}]^{-}$at $\mathrm{m} / \mathrm{z} 371,387$, and 357 were detected in mouse urine sample.

The molecular weight and $\mathrm{MS}^{2}$ fragmentation characteristic of each metabolite were compared with those of phillygenin for the more precise structural elucidation of the 
TABLE 2: Pharmacokinetic parameters of phillygenin after single oral (24 mg/kg) or iv $(12 \mathrm{mg} / \mathrm{kg})$ to mice.

\begin{tabular}{|c|c|c|}
\hline Parameter & po $(24 \mathrm{mg} / \mathrm{kg})$ & $i v(12 \mathrm{mg} / \mathrm{kg})$ \\
\hline$A U C_{0 \text {-last }}(\mu \mathrm{g} \cdot \mathrm{min} / \mathrm{mL})$ & 71.3 & 63.2 \\
\hline $\boldsymbol{A} \boldsymbol{U} \boldsymbol{C}_{0-\infty}(\mu \mathrm{g} \cdot \mathrm{min} / \mathrm{mL})$ & 72.5 & 76.2 \\
\hline Vd (mL/kg) & ${ }^{c} \mathrm{NC}$ & 300 \\
\hline $\mathrm{CL}(\mathrm{mL} / \mathrm{min} / \mathrm{kg})$ & 345 & 156 \\
\hline $\mathrm{C}_{0}(\mu \mathrm{g} / \mathrm{mL})$ & ${ }^{b} \mathrm{NQ}$ & 3.14 \\
\hline $\mathrm{C}_{\max }(\mu \mathrm{g} / \mathrm{mL})$ & 0.7 & -- \\
\hline $\mathbf{T}_{\max }(\min )$ & 30 & -- \\
\hline$t_{(1 / 2) \alpha}(\min )$ & ${ }^{c} \mathrm{NC}$ & 3.78 \\
\hline$t_{(1 / 2) \beta}(\min )$ & ${ }^{c} \mathrm{NC}$ & 630 \\
\hline A Half-life (min) & 54.8 & -- \\
\hline D Half-life (min) & 150 & ${ }^{a} \mathrm{NC}$ \\
\hline E Half-life (min) & 240 & ${ }^{a} \mathrm{NC}$ \\
\hline F (\%) & 56.4 & -- \\
\hline
\end{tabular}

${ }^{a} \mathrm{NC}=$ not calculated; low levels did not allow calculation of terminal half-life and $A U C_{\text {last- } \infty}$.

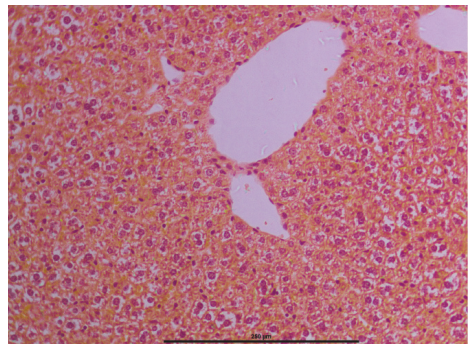

(a)

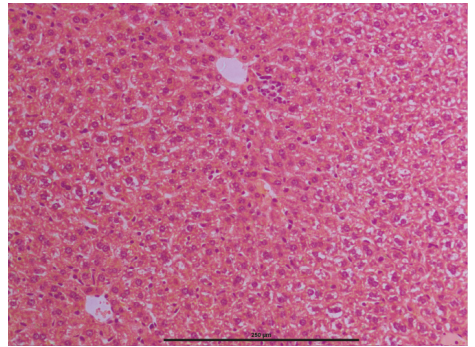

(d)

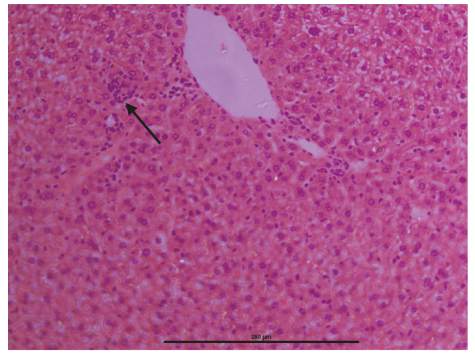

(g)

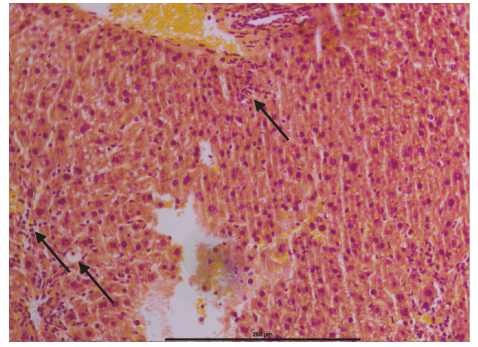

(b)

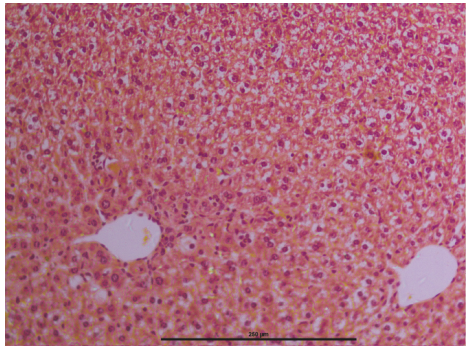

(e)

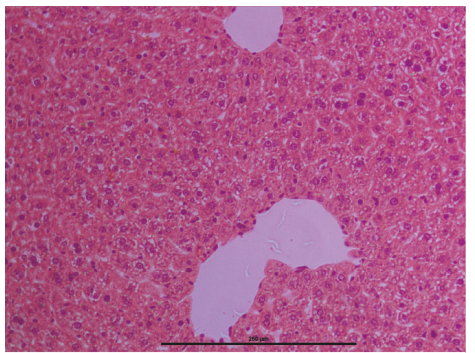

(h)

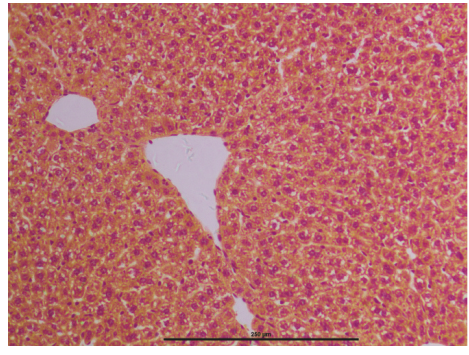

(c)

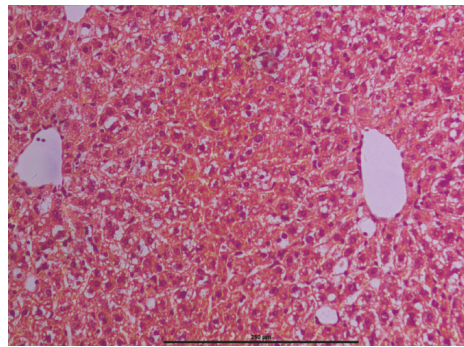

(f)

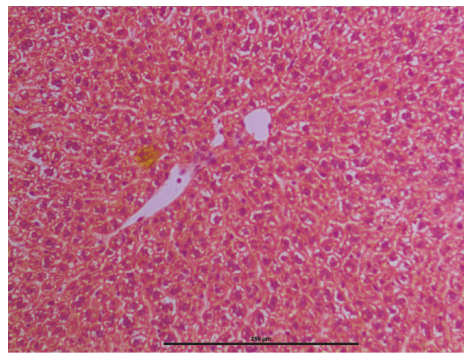

(i)

FIGURE 3: Effect of phillygenin/OFE on liver histopathology of $\mathrm{CCl}_{4}$-intoxicated mice. (a) Normal group liver section; (b) liver section of CCl ${ }_{4}{ }^{-}$ intoxicated group; (c) liver section of bifendate $+\mathrm{CCl}_{4}$ treated group; (d) liver section of phillygenin $(6 \mathrm{mg} / \mathrm{kg})+\mathrm{CCl}_{4}$-treated group; (e) liver section of phillygenin $(12 \mathrm{mg} / \mathrm{kg})+\mathrm{CCl}_{4}$-treated group; (f) liver section of phillygenin $(24 \mathrm{mg} / \mathrm{kg})+\mathrm{CCl}_{4}$-treated group. (g) Liver section of OFE $(150 \mathrm{mg} / \mathrm{kg})+\mathrm{CCl}_{4}$-treated group; (h) liver section of OFE $(300 \mathrm{mg} / \mathrm{kg})+\mathrm{CCl}_{4}$-treated group; (i) liver section of OFE $(600 \mathrm{mg} / \mathrm{kg})+$ $\mathrm{CCl}_{4}$-treated group. Original magnification $200 \times$ (a, b, c, d, e, and f). 


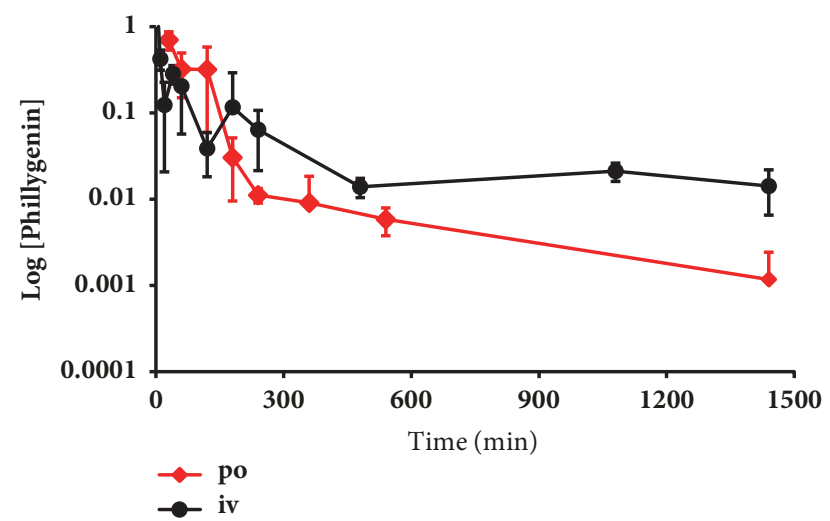

FIgURE 4: Plasma concentration-time curves after single oral dose administration of phillygenin $(24 \mathrm{mg} / \mathrm{kg})$ and single $i v$ dose administration of phillygenin $(12 \mathrm{mg} / \mathrm{kg})$. Concentrations are given in $\mu \mathrm{g} / \mathrm{mL}$ for plasma.

metabolites. Among them, the retention time and the $\mathrm{MS}^{2}$ of the molecular ion at $\mathrm{m} / \mathrm{z} 371$ (M0) were the same as those of phillygenin. Therefore, M0 can be affirmed as the unchanged phillygenin. The structures of metabolites were interpreted as follows. The molecular ion of M1 (m/z 387) and its main $\mathrm{MS}^{2}$ product ions at $\mathrm{m} / \mathrm{z} 372,356,163,151$, and 136 (Figure 6(b)) were almost the same as those of phillygenin, which means M1 might be the hydroxylated metabolite of phillygenin. The product ion of $\mathrm{M} 2$ at $\mathrm{m} / \mathrm{z} 357$ can lead to a characteristic $\mathrm{MS}^{2}$ product ion at $\mathrm{m} / \mathrm{z} 163,151,136$, and 121 (Figure 6(d)); compared with the fragment of phillygenin, M2 may be the demethylation metabolite of phillygenin.

\section{Discussion}

Hepatotoxicity induced by $\mathrm{CCl}_{4}$ is the most commonly used model system for the screening of hepatoprotective activity of plant extracts and drugs [10, 19]. Osmanthus fragrans' petroleum ether extract showed a great hepatoprotective effect on $\mathrm{CCl}_{4}$-induced hepatic injury mice, and phillygenin is the main ingredient in Osmanthus fragrans' petroleum ether extract. The purpose of this study is to determine the hepatoprotective effect of phillygenin/OFE on the $\mathrm{CCl}_{4}$-induced liver injury, and the pharmacokinetics and metabolism of phillygenin were also performed.

ABTS and DPPH assays are commonly used to evaluate antioxidant activities of natural compounds in foods or biological systems. Ascorbic acid, used as a positive control, is a naturally occurring organic compound which can block some of the damage caused by free radicals [20, 21]. Antioxidant active assays show that phillygenin can bleach the DPPH and ABTS radical immediately and possess better effective ABTS radical-scavenging activity than ascorbic acid, which suggests that phillygenin could be classified as dynamic antioxidants.

$\mathrm{CCl}_{4}$ can be metabolized by CYP2E1 and produce free radical such as $\mathrm{CCl}_{3}$. and $\mathrm{CCl}_{3} \mathrm{OO} \cdot$ which can bind to macromolecules and initiate the chain reaction of lipid peroxidation to cause liver cell damage [22]. Chemicals that reduce CYP2E1 activity may alleviate the toxicity caused by $\mathrm{CCl}_{4}$, and it was also expected that a radical scavenger may ameliorate $\mathrm{CCl}_{4}$ induced liver toxicity $[22,23]$. A report indicates that CYP2E1 inhibitor but not antioxidants can totally or partially prevent $\mathrm{CCl}_{4}$ induced hepatic toxicity at an early time, suggesting that reducing CYP2E1 activity could be a better strategy than antioxidant to prevent $\mathrm{CCl}_{4}$-induced early hepatotoxicity [24]. Present study shows that phillygenin can inhibit the activity of CYP2E1 with $K_{\mathrm{i}}$ of $2.40 \mu \mathrm{M}$. The results suggest that inhibition of the activity of CYP2E1 might be a mechanism of phillygenin that plays the hepatoprotective role in $\mathrm{CCl}_{4}$ induced early liver injury in mice.

The blood serum and liver enzymes (such as ALT and AST) were used as indicators of hepatic damage. The damaged liver cells can spill ALT and AST into blood, raising these two enzymes levels in blood and signaling the liver damage. Present study shows that $\mathrm{CCl}_{4}$-induced liver toxicity could lead to the increased activities of ALT and AST in serum that could be attributed to the liver damage resulting in the release of functional enzymes from hepatocytes. However, the increased levels of ALT and AST in serum were significantly decreased by pretreatment with phillygenin/OFE, implying that phillygenin/OFE may protect the hepatocytes against toxicity induced by $\mathrm{CCl}_{4}$. As the marker of lipid peroxidation, MDA levels in phillygenin/OFE group are almost the same as the normal control group, which means phillygenin/OFE can block the lipid peroxidation. Based on the current results, OFE appears to decrease MDA levels more than phillygenin, indicating other antioxidants in OFE. There is a report that there are five phenolic compounds in O. fragrans, which may contribute to decreasing MDA levels [3]. SOD is an intracellular antioxidant enzyme that protects the cell against oxidative stress. Phillygenin/OFE significantly decreases the activity of $\mathrm{SOD}$ in $\mathrm{CCl}_{4}$-induced mice liver and the levels are almost the same as the normal control group. Histopathological showed severe liver damage in $\mathrm{CCl}_{4}$ group mice such as centrilobular necrosis, hepatocyte ballooning, and infiltration of inflammatory cells into the portal tract and sinusoid in the necrotic lesion. Pretreatment with phillygenin/OFE can reverse the hepatic lesions produced by $\mathrm{CCl}_{4}$.

Although phillygenin has many pharmacological activities, there is only one report about the pharmacokinetics study of phillygenin in rat [25], which shows quick elimination after iv administration in the rat. There is limited information about the absorption and the first pass effect with which a drug is absorbed after oral administration, its bioavailability should be assessed. Pharmacokinetics study shows that phillygenin can be absorbed quickly with the absorption half-life of $54.8 \mathrm{~min}$ and efficiently with the bioavailability of approximately 56.4\%. After absorption, phillygenin distributed quickly with the distribution half-life of $150 \mathrm{~min}$ and widely with the $\mathrm{Vd}$ of $300 \mathrm{~mL} / \mathrm{kg}$ in mice. Two metabolites, hydroxylated and demethylation, were identified in rat urine sample after oral administration of phillygenin.

\section{Conclusions}

Osmanthus fragrans is a plant that has been used in traditional Chinese medicine to treat menopathies. The extract of Osmanthus fragrans flowers showed neuroprotective, freeradical scavenging, antioxidative effects in vitro. Phillygenin, 


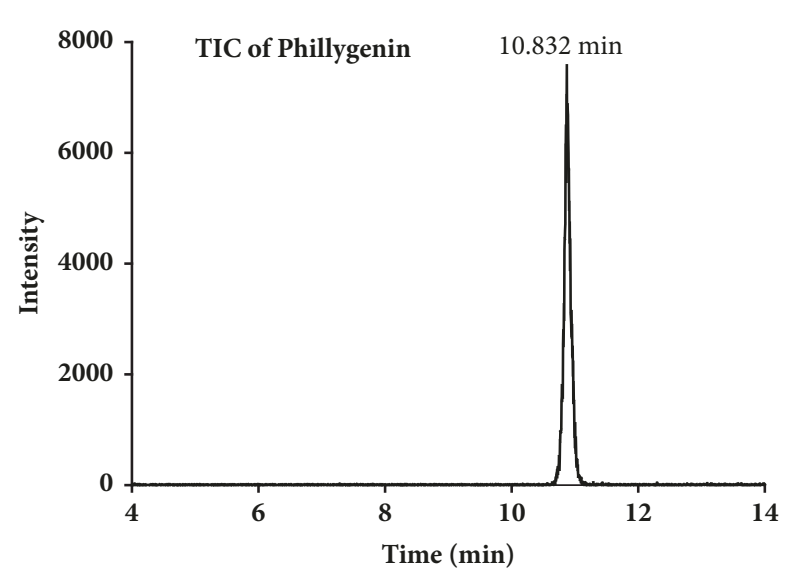

(a)

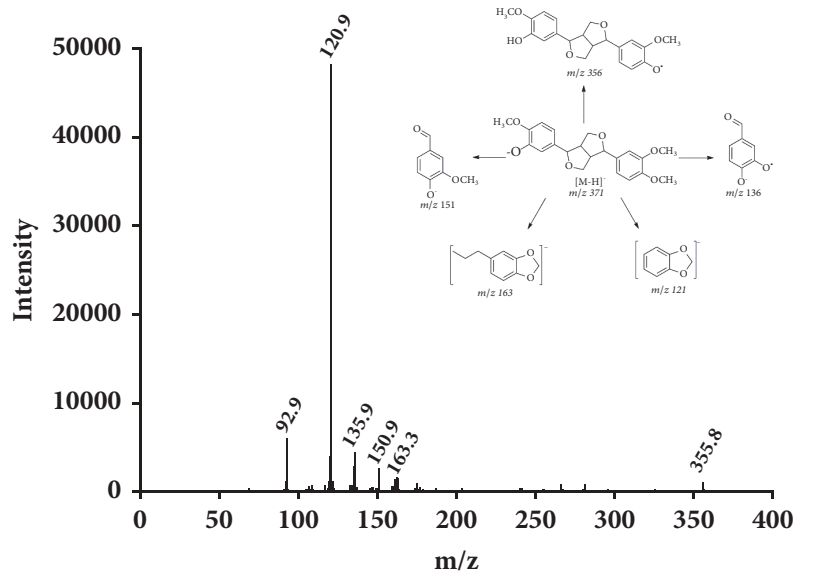

(b)

FIGURE 5: UPLC-MS/MS spectra of phillygenin. (a) Total ion chromatogram of phillygenin; (b) UPLC-MS/MS product ion spectrum of phillygenin.

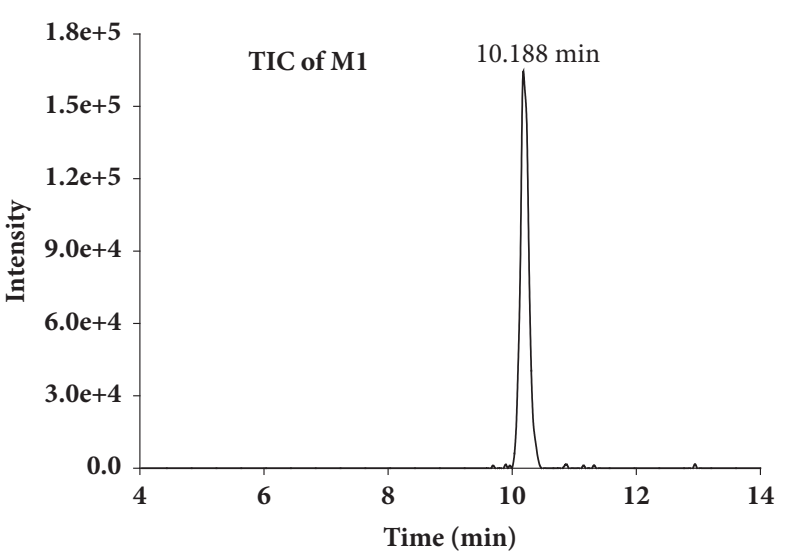

(a)

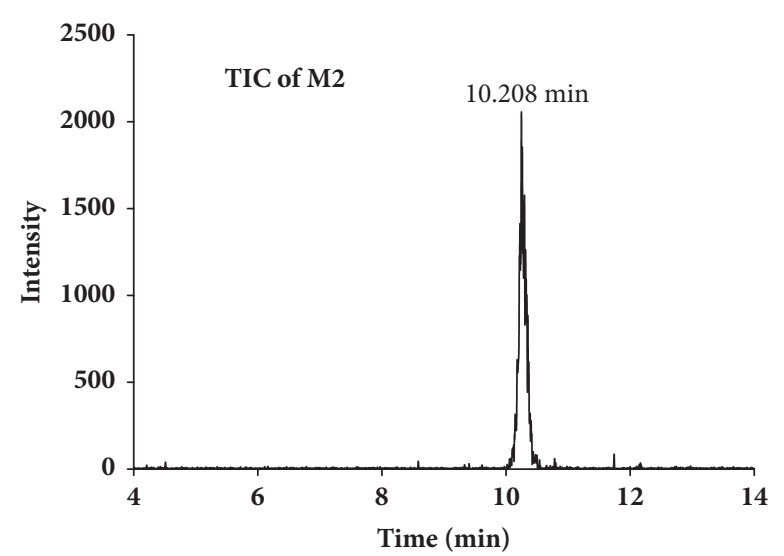

(c)

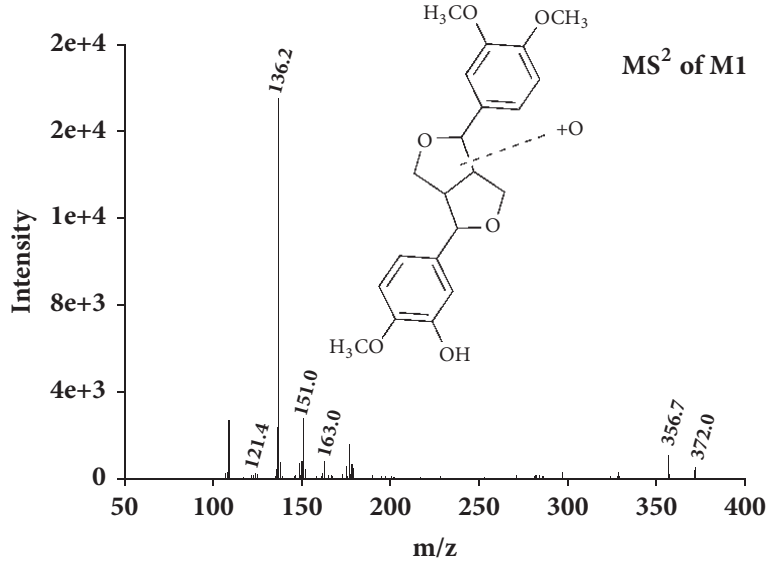

(b)

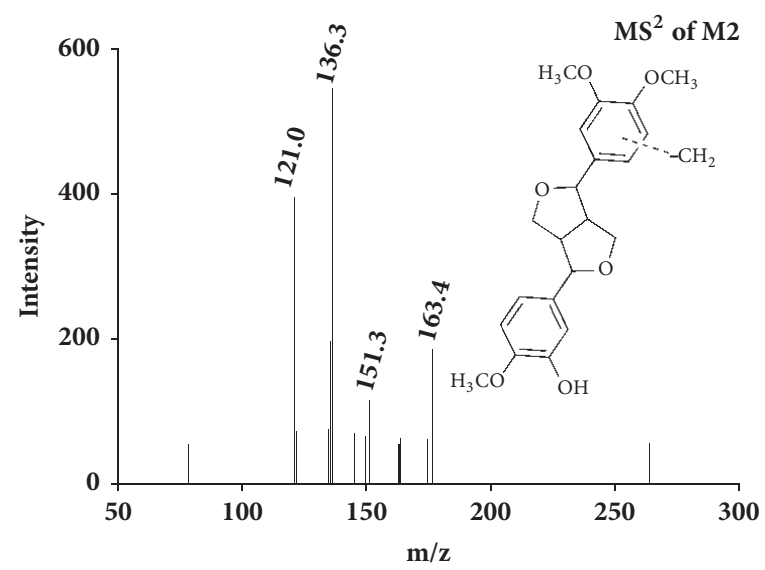

(d)

FIGURE 6: UPLC-MS/MS spectra of the metabolites of phillygenin. (a) Total ion chromatogram of M1; (b) UPLC-MS/MS product ion spectrum of M1; (c) total ion chromatogram of M2; (d) UPLC-MS/MS product ion spectrum of M2. 
one of the major ingredients in Osmanthus fragrans, shows great hepatoprotective effects on $\mathrm{CCl}_{4}$-induced liver injury in mice, antioxidant activity, and inhibition on CYP2E1 in vitro. Meanwhile, as an oral administrated compound, phillygenin owns good bioavailability. These results suggested that phillygenin could be explored as new and potential natural antioxidants and hepatoprotective agents for use in functional foods.

$\begin{array}{ll}\text { Abbreviations } \\ \text { CCl4: } & \text { Carbon tetrachloride } \\ \text { OFE: } & \text { Osmanthus fragrans flower extract } \\ \text { CYP2E1: } & \text { Cytochrome P450 2E1 } \\ \text { EDTA: } & \text { Ethylenediamine tetracetic acid } \\ \text { DPPH: } & \text { Diphenyl-2-picrylhydrazyl } \\ \text { NADPH: } & \text { B-Nicotinamide adenine dinucleotide } \\ & 2^{\prime} \text {-phosphate reduced tetrasodium salt } \\ & \text { hydrate } \\ \text { UPLC: } & \text { Ultra-performance liquid chromatography } \\ \text { AST: } & \text { Aspartate aminotransferase } \\ \text { alanine ALT: } & \text { Aminotransferase } \\ \text { SOD: } & \text { Superoxide dismutase } \\ \text { MDA: } & \text { Malondialdehyde } \\ \text { QC: } & \text { Quality control } \\ \text { AUC: } & \text { The area under the mean } \\ & \text { concentration-time curve } \\ \text { Vd: } & \text { Volume distribution } \\ \text { Cl: } & \text { Clearance } \\ \text { C }: & \text { Initial concentration. }\end{array}$

\section{Data Availability}

The data used to support the findings of this study are available from the corresponding author upon request.

\section{Disclosure}

Longjiang $\mathrm{Yu}$ and Zhihong Peng are co-corresponding authors.

\section{Conflicts of Interest}

The authors declare that they have no financial or nonfinancial conflicts of interest.

\section{Acknowledgments}

The study was supported by Science Foundation for the Youth Scholars of Hubei Provincial Department of Education for Science and Technology Research Program (no. Q2017007).

\section{Supplementary Materials}

Figure S1 shows the specificity of developed method for phillygenin quantification. Tables $\mathrm{S} 1$ gives the precision, accuracy, extraction recovery, and matrix effects of phillygenin in spiked mouse plasma, respectively. Table S2 reports the stability of phillygenin in mouse plasma under various conditions. (Supplementary Materials)

\section{References}

[1] H. Ômura, K. Honda, and N. Hayashi, "Floral scent of Osmanthus fragrans discourages foraging behavior of cabbage butterfly, Pieris rapae," Journal of Chemical Ecology, vol. 26, no. 3, pp. 655-666, 2000.

[2] L.-M. Wang, M.-T. Li, W.-W. Jin, S. Li, S.-Q. Zhang, and L.-J. $\mathrm{Yu}$, "Variations in the components of Osmanthus fragrans Lour. essential oil at different stages of flowering," Food Chemistry, vol. 114, no. 1, pp. 233-236, 2009.

[3] C.-Y. Hung, Y.-C. Tsai, and K.-Y. Li, "Phenolic antioxidants isolated from the flowers of Osmanthus fragrans," Molecules, vol. 17, no. 9, pp. 10724-10737, 2012.

[4] H.-H. Lee, C.-T. Lin, and L.-L. Yang, "Neuroprotection and free radical scavenging effects of Osmanthus fragrans," Journal of Biomedical Science, vol. 14, no. 6, pp. 819-827, 2007.

[5] A. Kumar and D. Ganjewala, "Antimicrobial Properties of Osmanthus fragrans (Lour)," Research Journal of Medicinal Plant, vol. 1, no. 1, pp. 21-24, 2007.

[6] W. Song, M. Z. Ao, Y. Shi, L. F. Yuan, X. X. Yuan, and L. J. Yu, "Interaction between phillygenin and human serum albumin based on spectroscopic and molecular docking," Spectrochimica Acta Part A: Molecular and Biomolecular Spectroscopy, vol. 85, no. 1, pp. 120-126, 2012.

[7] W. Y. X. Q. T. Kang, J. M. Wang, X. M. Li, C. F. Li, and Y. L. ong, "Hypolipemic effective constituent phillygenin of Forsythia suspensa, its preparation method and application," Faming Zhuanli Shenqing Gongkai Shuomingshu, vol. CN101537046, p. 11, 2009.

[8] C.-C. Chen, H.-Y. Chen, M.-S. Shiao, Y.-L. Lin, Y.-H. Kuo, and J.-C. Ou, "Inhibition of low density lipoprotein oxidation by tetrahydrofurofuran lignans from Forsythia suspensa and Magnolia coco," Planta Medica, vol. 65, no. 8, pp. 709-711, 1999.

[9] L. P. Xiang, J. C. Eun, H. J. Moon, and J. Cui, "Cytoprotective effect of lignans from Forsythia suspensa against peroxynitriteinduced LLC-PK1 cell damage," Phytotherapy Research, vol. 23, no. 7, pp. 938-942, 2009.

[10] N. Brautbar and J. Williams II, "Industrial solvents and liver toxicity: risk assessment, risk factors and mechanisms," International Journal of Hygiene and Environmental Health, vol. 205, no. 6, pp. 479-491, 2002.

[11] L.-C. Lin, S.-H. Li, Y.-T. Wu, K.-L. Kuo, and T.-H. Tsai, "Pharmacokinetics and urine metabolite identification of dehydroevodiamine in the rat," Journal of Agricultural and Food Chemistry, vol. 60, no. 7, pp. 1595-1604, 2012.

[12] F. Fratianni, M. N. Ombra, A. Cozzolino et al., "Phenolic constituents, antioxidant, antimicrobial and anti-proliferative activities of different endemic Italian varieties of garlic (Allium sativum L.)," Journal of Functional Foods, vol. 21, pp. 240-248, 2016.

[13] W.-M. Chai, C.-M. Chen, Y.-S. Gao et al., "Structural analysis of proanthocyanidins isolated from fruit stone of chinese hawthorn with potent antityrosinase and antioxidant activity," Journal of Agricultural and Food Chemistry, vol. 62, no. 1, pp. 123-129, 2014.

[14] M. L. Zeraik, E. F. Queiroz, L. Marcourt et al., "Antioxidants, quinone reductase inducers and acetylcholinesterase inhibitors from Spondias tuberosa fruits," Journal of Functional Foods, vol. 21, pp. 396-405, 2016. 
[15] Y. Ohashi, K. Yamada, I. Takemoto, T. Mizutani, and K.-I. Saeki, "Inhibition of human cytochrome P450 2E1 by halogenated anilines, phenols, and thiophenols," Biological \& Pharmaceutical Bulletin, vol. 28, no. 7, pp. 1221-1223, 2005.

[16] G. T. Liu, "From the study of Fructus schizandrae to the discovery of biphenyl dimethyl-dicarboxylate," Acta Pharmaceutica Sciencia, vol. 18, no. 9, pp. 714-720, 1983.

[17] G. T. Liu, H. L. Wei, and Z. Y. Song, "Further studies on the protective action of biphenyl dimethyl-dicarboxylate (BDD) against experimental liver injury in mice (author's transl)," Acta Pharmaceutica Sciencia, vol. 17, no. 2, pp. 101-106, 1982.

[18] S.-Y. Pan, R. Yang, H. Dong, Z.-L. Yu, and K.-M. Ko, "Bifendate treatment attenuates hepatic steatosis in cholesterol/bile salt- and high-fat diet-induced hypercholesterolemia in mice," European Journal of Pharmacology, vol. 552, no. 1-3, pp. 170-175, 2006.

[19] W.-G. Yu, J. Qian, and Y.-H. Lu, "Hepatoprotective effects of $2^{\prime}, 4^{\prime}$-dihydroxy-6' -methoxy- $3^{\prime}, 5^{\prime}$-dimethylchalcone on $\mathrm{CCl}_{4}$ induced acute liver injury in mice," Journal of Agricultural and Food Chemistry, vol. 59, no. 24, pp. 12821-12829, 2011.

[20] S. Dudonné, X. Vitrac, P. Coutiére, M. Woillez, and J.-M. Mérillon, "Comparative study of antioxidant properties and total phenolic content of 30 plant extracts of industrial interest using DPPH, ABTS, FRAP, SOD, and ORAC assays," Journal of Agricultural and Food Chemistry, vol. 57, no. 5, pp. 1768-1774, 2009.

[21] E. A. Shalaby and S. M. M. Shanab, "Comparison of DPPH and ABTS assays for determining antioxidant potential of water and methanol extracts of Spirulina platensis," Indian Journal of Marine Sciences, vol. 42, no. 5, pp. 556-564, 2013.

[22] L. W. D. Weber, M. Boll, and A. Stampfl, "Hepatotoxicity and mechanism of action of haloalkanes: carbon tetrachloride as a toxicological model," Critical Reviews in Toxicology, vol. 33, no. 2, pp. 105-136, 2003.

[23] Y. Aniya, T. Koyama, C. Miyagi et al., "Free radical scavenging and hepatoprotective actions of the medicinal herb, Crossocephalum crepidioides from the Okinawa Islands," Biological \& Pharmaceutical Bulletin, vol. 28, no. 1, pp. 19-23, 2005.

[24] L. Knockaert, A. Berson, C. Ribault et al., "Carbon tetrachloride-mediated lipid peroxidation induces early mitochondrial alterations in mouse liver," Laboratory Investigation, vol. 92, no. 3, pp. 396-410, 2012.

[25] L.-H. Ye, Y.-X. Li, C. Peng, X.-H. Gong, and X.-G. Zheng, "Determination of phillygenin in rat plasma by highperformance liquid chromatography and its application to pharmacokinetic studies," European Journal of Drug Metabolism and Pharmacokinetics, vol. 38, no. 3, pp. 201-207, 2013. 

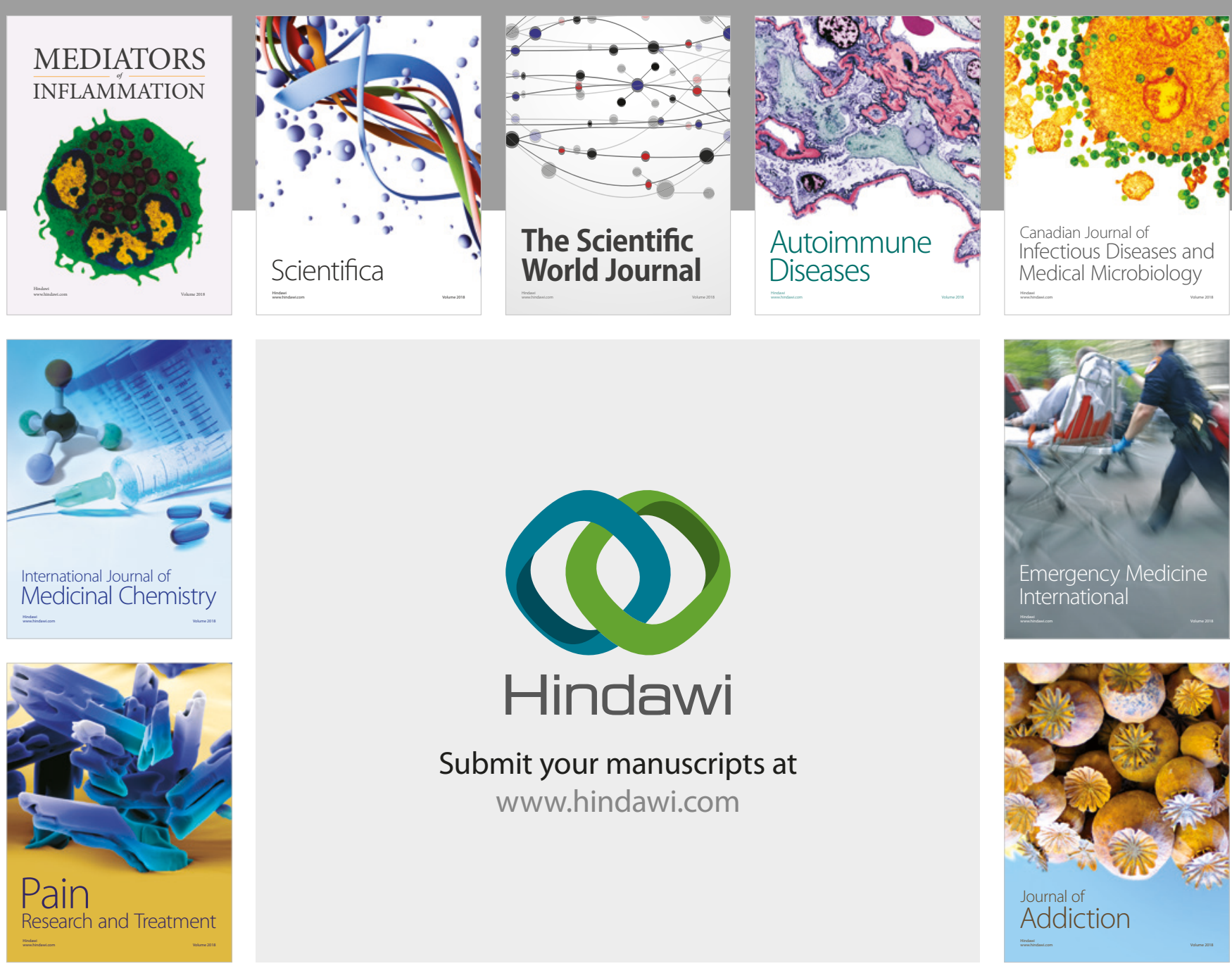

Canadian Journal of
Infectious Diseases and Medical Microbiology

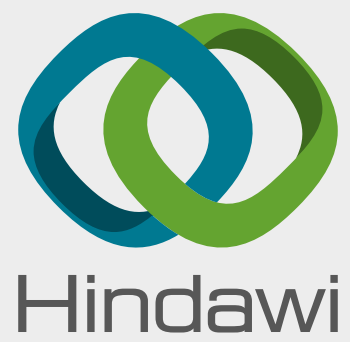

Submit your manuscripts at

www.hindawi.com
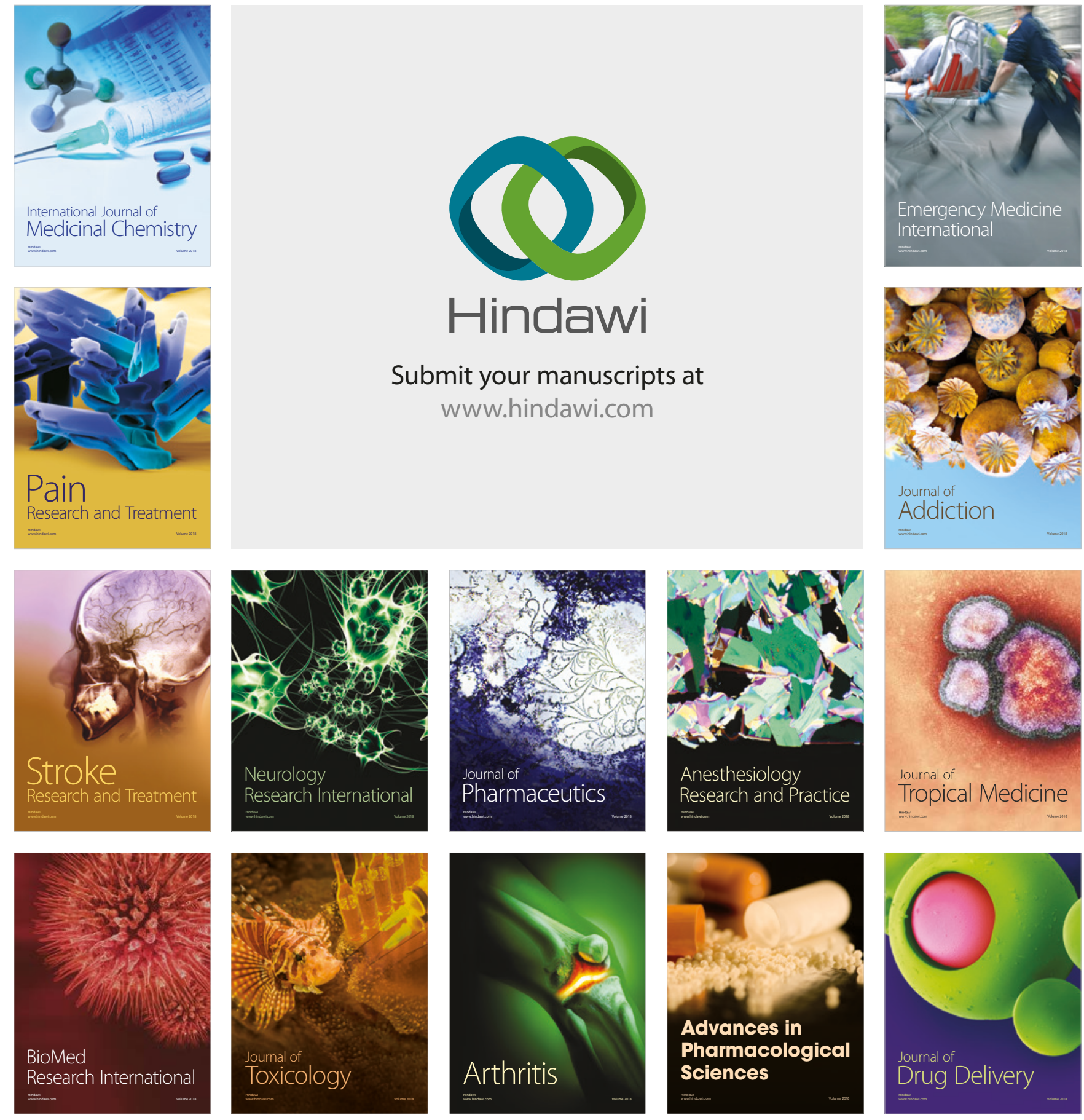